\title{
Competing explanations for knowledge exchange: Technology sharing within the globally dispersed R\&D of the multinational enterprise
}

\author{
Prescott C. Ensign \\ Louis Hébert
}

\begin{abstract}
This paper explores five competing theories for technological knowledge sharing within the globally dispersed R\&D function of the multidivisional, multinational firm. These five broad explanations for why a knowledge transaction occurs are: (1) economic, (2) technological, (3) organizational, (4) geographic, and (5) sociological. In addition to occurrence, likelihood of knowledge exchange success prompted by various explanations is considered. Ultimately the determination of which argument - or combination of arguments - offers the greatest explanatory power for the sharing of intermediate technological knowledge may be answered empirically.
\end{abstract}

With regard to knowledge, the issue of transferability is important, not only between firms, but even more critically, within the firm. (Grant, $1996: 111$ )

Bringing different perspectives to bear on a single, overriding issue is one way to try to improve our understanding of observed phenomenon, however complex they may be. (Hagstrom \& Chandler, 1999 : 12)

\section{Introduction}

The organization and management of innovative activities in the multidivisional, multinational firm is the setting for this paper. A growing interest in this issue is at least partly related to the importance of technology in the present competitive environment. ${ }^{1}$ For a firm with globally distributed R\&D operations, issues of coordination and control are of major significance (Ensign, 1999 ). "In high-technology environments, rapid technological change means that the value of a firm's existing knowledge is quickly eroded" (Hayton \& Zahra, 2005 : 256). The need to optimize and/or leverage technological knowledge that resides in different individuals or groups is vital. The sharing of resources such as scientific know-how is a major contributor to the achievement of firm growth and survival (Santoro \& Saparito, 2006; Tarn, 2006 ).

\footnotetext{
Ensign, P.C. and Hébert, L. (2009) Competing Explanations for Knowledge Exchange: Technology Sharing within the Globally Dispersed R\&D of the Multinational, Multidivisional Firm. Journal of High Technology Management Research. 20(1): 75-85. doi $10.1016 /$ j.hitech.2009.02.004
}

\footnotetext{
${ }^{1}$ It should be noted that this is not an entirely recent concern, Dunning (1958) observed the two-way exchange of technological knowledge within the multinational enterprise.
} 


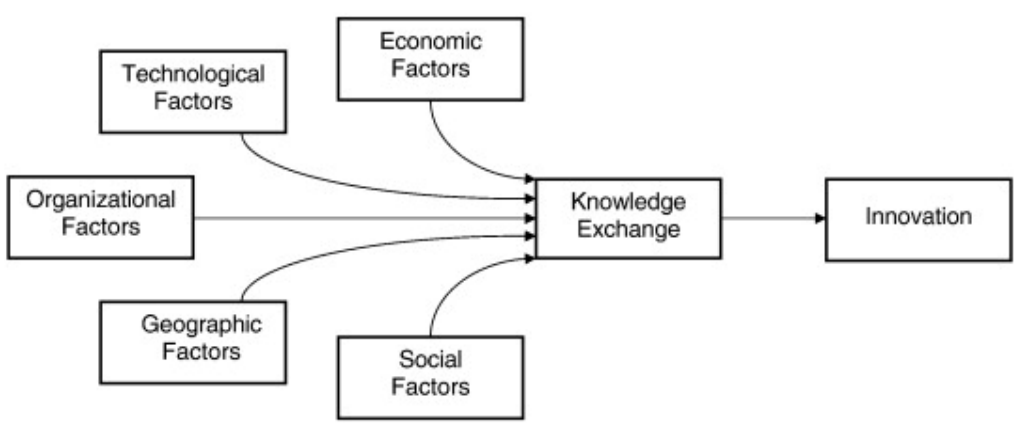

Figure 1 Conceptual model

Based on a review of literature, the multidivisional, multinational firm can be conceptualized as a network of transactions. ${ }^{2}$ Gupta and Govindarajan (1991: 770) describe these transactions as: capital flows; product flows; and knowledge flows. Bartlett and Ghoshal (1991: 169-170) also describe three flows in the multinational enterprise (MNE): flow of goods; flow of information; and flow of resources (including the transfer of technology and movement of personnel). The flow of technological knowledge between different $\mathrm{R} \& \mathrm{D}$ groups in an MNE is described here as technological knowledge sharing rather than technology transfer. Technology transfer has usually been used to indicate an exchange involving a finished product, a completed or self-contained parcel of technology (cf. Gopalakrishnan \& Santoro, 2004 ). Technological knowledge sharing is used to represent an exchange of an intermediate good-the transmission or communication of scientific know-how from one context to another.

As Grant (1996: 114) states "transferring knowledge is not an efficient approach to integrating knowledge ...." Iansiti (1998: 2) too insists integration is the proper description; noting that "a technology cannot be separated from other technologies. Technologies act in conjunction with one another"- - value is added through integration. Leonard-Barton (1990) indicates that there are shortcomings in the term transfer. Transfer connotes movement from one place to another. In the case of capital flows and product flows there is movement and no change in properties. The same cannot be said of knowledge flows, with the exception, perhaps, of simple explicit knowledge. ${ }^{3}$ Knowledge flows involve sharing — defined as using, participating in, joining with others, taking part in, and receiving equally or together-which goes beyond where transfer or diffusion leave off (Collins \& Hitt, 2006 ). A knowledge transaction involves improvement in knowledge. ${ }^{4}$ Our focus is on technological knowledge transactions, described as an exchange involving a source and a recipient. Technological knowledge is conceptualized as intermediate technology, scientific know-how, skills, and capabilities.

The focus of this paper is on understanding the explanations or reasons for technological knowledge sharing between dispersed R\&D workers and groups. These are often described as motivations, needs, desires, or reasons why the sharing of technological knowledge occurs in the MNE. We suggest that there are five major competing theories or explanations for the occurrence and success of technological knowledge sharing. These are: (1) economic explanations, (2) technological explanations, (3) organizational explanations, (4) geographic explanations, and (5) sociological explanations (see Fig. 1 ). In each case, there is recognition of potential benefits that may result from sharing scientific know-how. Though this paper centers primarily on the intra-firm sharing of technological knowledge (Table 1 ) inter-firm sharing of technological knowledge was considered (Table 2 ).

Based on a review of the literature, technological knowledge sharing must be viewed as a process. This process includes: recognition of a need or opportunity; a search for a source that can help meet this need or opportunity; and an exchange involving a source and a recipient facilitated by management decisions and appropriate coordination/integration mechanisms. Understanding this process helps to explain the complexities involved in a technological knowledge transaction. Hagstrom and Chandler (1999: 1) indicate partial theories abound and that "more complete theories" to explain the functioning of the firm in an ever increasing international environment remain elusive. "Perhaps we have reached the limit of approaches firmly anchored in one [perspective]" (Hagstrom \& Chandler, $1999: 1$ ).

\section{Economic explanations for knowledge exchange}

Economic explanations focus on knowledge being shared to create economic value through greater efficiency. In the context of an R\&D task, such efficiencies may be realized through improvements in cost and time. From an economic perspective, the constraints (cost and time) within an R\&D group may provide the motivation for accessing technological knowledge in other R\&D groups located elsewhere in the MNE. Lower cost and completion of the R\&D task on time (or in less time) may be compelling reasons why an R\&D group will initiate a search (internal and/or external) for the scientific know-how it needs to accomplish its R\&D task goals. In many

${ }^{2}$ As Williamson (1975: xi) states in support of Commons' (1934) view, "the transaction is the ultimate unit of microeconomic analysis."

3 Thrift (1985: 368) allows no such exceptions: "no two actors can communicate knowledge perfectly."

${ }^{4}$ Strictly speaking, it is quite imaginable that a knowledge transaction could result in a situation in which the knowledge received was altered in such a manner that it became less valuable or even detrimental. Clearly this would not be improvement in knowledge - though, it would result in new knowledge. 
Table 1 Inter-firm studies of knowledge sharing and the factors explored.

\begin{tabular}{|c|c|c|c|c|c|}
\hline & Economic & Technological & Organizational & Geographic & Sociological \\
\hline $\begin{array}{l}\text { Carter } \\
\text { (1989) }\end{array}$ & $\begin{array}{l}\text { Reciprocity and trust } \\
\text { between source and } \\
\text { recipient promote } \\
\text { knowledge exchange. }\end{array}$ & & & & $\begin{array}{l}\text { Reciprocity and trust } \\
\text { between source and } \\
\text { recipient promote } \\
\text { knowledge exchange. }\end{array}$ \\
\hline $\begin{array}{l}\text { Cohen and } \\
\text { Levinthal } \\
\text { (1990) }\end{array}$ & & $\begin{array}{l}\text { Technological commonalities } \\
\text { (and differences) between } \\
\text { the recipient and the } \\
\text { knowledge being transmitted } \\
\text { promote knowledge exchange. }\end{array}$ & & & \\
\hline $\begin{array}{r}\text { Schrader } \\
(1991)\end{array}$ & $\begin{array}{l}\text { Economic concerns are the } \\
\text { primary driver for } \\
\text { knowledge sharing. }\end{array}$ & & & & $\begin{array}{l}\text { Social interaction may } \\
\text { be a necessary though } \\
\text { insufficient condition for } \\
\text { knowledge sharing. }\end{array}$ \\
\hline $\begin{array}{r}\text { Dodgson } \\
(1993)\end{array}$ & & & $\begin{array}{l}\text { Firm culture influences } \\
\text { the degree of knowledge } \\
\text { receptivity. }\end{array}$ & & $\begin{array}{l}\text { Trust must transcend } \\
\text { the individual level and } \\
\text { aggregate to the group. }\end{array}$ \\
\hline $\begin{array}{l}\text { Powell, } \\
\text { Koput, and } \\
\text { Smith- } \\
\text { Doerr } \\
\text { (1996) }\end{array}$ & & & $\begin{array}{l}\text { Strategic and social } \\
\text { factors are inextricably } \\
\text { bound together. }\end{array}$ & & $\begin{array}{l}\text { Strategic and social factors } \\
\text { are inextricably bound } \\
\text { together. }\end{array}$ \\
\hline $\begin{array}{l}\text { Lane and } \\
\text { Lubatkin } \\
\text { (1998) }\end{array}$ & & $\begin{array}{l}\text { Similarity in knowledge bases a } \\
\text { structures and compensation pc } \\
\text { knowledge exchange. }\end{array}$ & $\begin{array}{l}\text { Ind organizational } \\
\text { olicies promote }\end{array}$ & & \\
\hline $\begin{array}{l}\text { Soh and } \\
\text { Roberts } \\
\text { (1998) }\end{array}$ & & $\begin{array}{l}\text { Technological capability builds } \\
\text { social capital and promotes } \\
\text { knowledge exchange. }\end{array}$ & & & $\begin{array}{l}\text { Social capital builds techno } \\
\text { logical capability } \\
\text { and promotes knowledge } \\
\text { exchange. }\end{array}$ \\
\hline $\begin{array}{l}\text { Adams } \\
\text { (1999) }\end{array}$ & & $\begin{array}{l}\text { Commonalities between the } \\
\text { recipient and the knowledge } \\
\text { in the exchange promoten } \\
\text { knowledge sharing. }\end{array}$ & & $\begin{array}{l}\text { Source new hires to } \\
\text { absorb location specific } \\
\text { technological knowledge. }\end{array}$ & \\
\hline $\begin{array}{c}\text { Sakakibara } \\
\text { (1999) }\end{array}$ & $\begin{array}{l}\text { Consortia may enable } \\
\text { investment in projects with } \\
\text { high uncertainly (ratio of } \\
\text { risk to returns). }\end{array}$ & $\begin{array}{l}\text { Technological differences } \\
\text { between source and recipient } \\
\text { promote knowledge exchange. }\end{array}$ & & $\begin{array}{l}\text { Consortia may bring } \\
\text { dispersed parties together } \\
\text { for common purposes. }\end{array}$ & \\
\hline
\end{tabular}

cases, some formal coordination or control mechanisms may be needed to ensure that R\&D task deadlines and budget requirements are met. Technological knowledge sharing can provide economic benefits at the corporate, unit, group, and individual level.

In a study on informal technological knowledge transfer between firms, Schrader (1991) suggests that economic benefits are a primary explanation for the exchange of technical information between individuals in different firms. Although trading or the transfer of scientific know-how may be facilitated by the strength of the relationship/friendship that exists between recipient and source, Schrader (1991) suggests that economic reasons are generally the most significant factor in the "transfer decision." He also suggests that the concept of reciprocity in economic benefits can be the basis for a knowledge transaction. Not only does the recipient hope the transaction will translate into economic benefits, but the source is also motivated by the potential for economic gain. The characteristic of a relationship that deters opportunism is "expectation of a continuing supply of new knowledge" (Buckley \& Carter, 1999 : 88).

A renewed interest in resources - largely the result of studies that take a resource-based view of the firm-has helped to emphasize the importance of optimization or greater utilization of resources - particularly those that are intangible and idiosyncratic - to gain competitive advantage. Technological knowledge sharing among the various R\&D groups of an MNE takes place to achieve synergy through economies of scope. Sharing of complementary intellectual resources generates economic rents. Consistent with the resource-based view, Buckley and Carter (1999) indicate that synthesizing knowledge is an entrepreneurial activity with substantial economic benefits.

Numerous studies have focused on the advantages of a multiunit (Chandler, 1962; Hansen, 1996; Williamson, 1970 ) and multinational (Bartlett \& Ghoshal, 1991; Kogut, 1983, 1990 ) firm. These studies suggest that organizing and managing the firm as an integrated network can provide significant economic returns. Because multiple and/or geographically dispersed units have specialized or differentiated resources, the firm has the option or ability to leverage assets for value creation. According to Gupta and Govindarajan (1993: 330), the economic argument is that exchange of knowledge can be handled "more effectively and efficiently through internal organizational rather than external market mechanisms; this is due to the fact that external transactions in knowledge are susceptible to several market imperfections including recognition problems, disclosure problems, and negative externalities." It should be pointed out that there may be markets for knowledge within the firm and that such drawbacks - as found external to the firm - may exist unless mechanisms to motivate and enforce exchange are present. 
Table 2 Intra-firm studies of knowledge sharing and the factors explored.

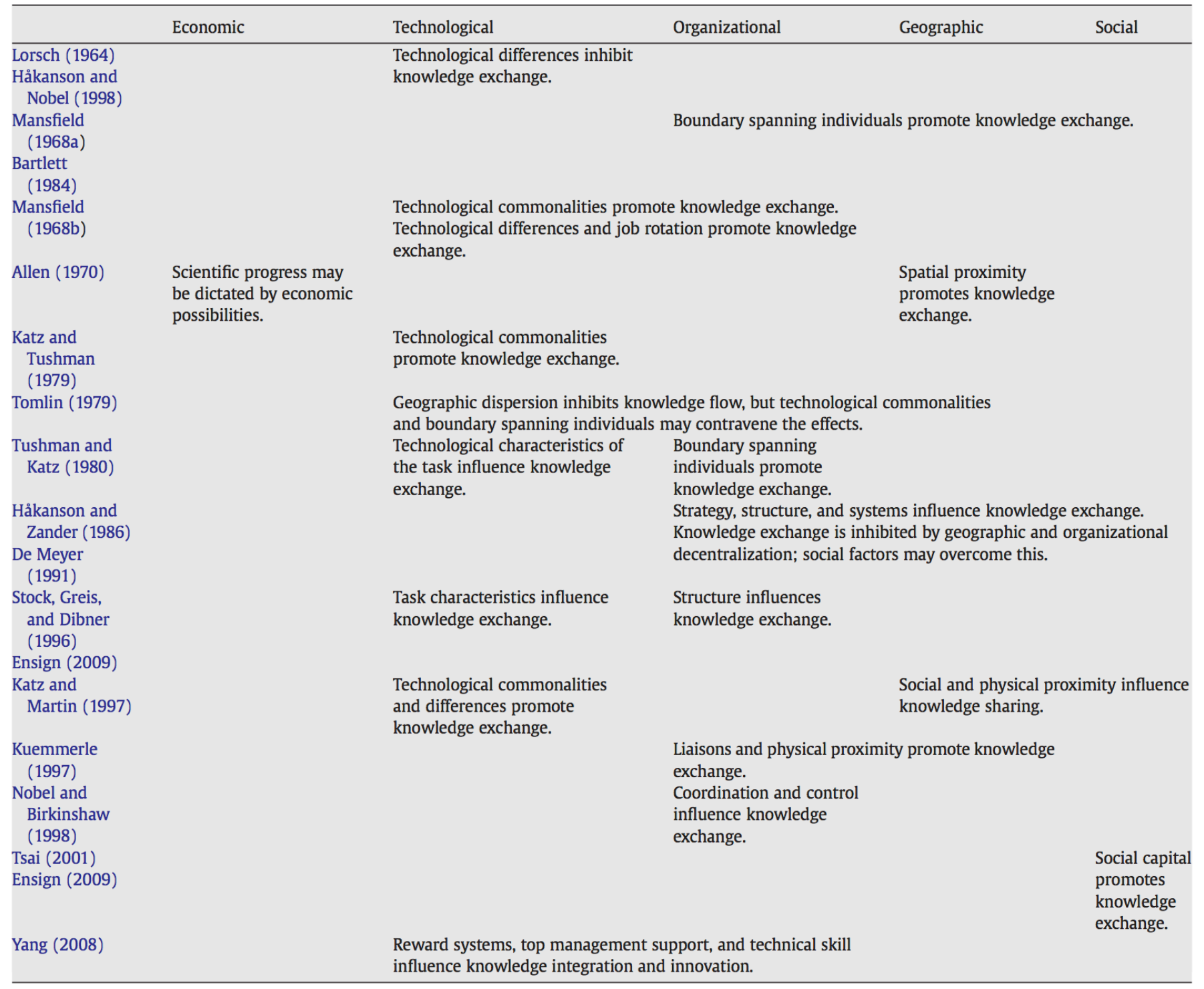

Arrow (1971) identifies a paradox for knowledge; the would-be recipient of knowledge is reluctant to make an offer before the knowledge is revealed (and its value assessed) while at the same time the would-be provider is hesitant to reveal the knowledge (less its value be appropriated). Without precautions taken to alter conditions of exchange, this same conundrum may apply for transactions involving sharing of technological knowledge within the firm. Fortunately, the MNE is an excellent vehicle for nurturing the requisite conditions for exchange of tacit technological knowledge. Nobel and Birkinshaw (1998) affirm that the economic rationale holds; MNE's utilize (exploit) their existing base of technological know-how for reasons of efficiency. Often times the MNE formally recognizes an organizational sub-group — a "center"—-for particular efficiency or expertise (Ensign, Birkinshaw, \& Frost, 2000 ).

In assessing knowledge transactions, Gupta and Govindarajan (1991) suggest that "volume and criticality" describe "magnitude" of knowledge flows. In this paper, it is proposed that importance or "criticality" influence the occurrence or propensity to undertake transactions. These may also impact the success of a knowledge transaction. According to Buckley and Carter (1999: 80 ), combining knowledge within the firm is a "key component in achieving the strongest possible competitive stance." Although there are economic arguments for and against exchange of knowledge, ${ }^{5}$ based on the economic explanations presented in this section, the following simple proposition is suggested.

Proposition 1. The greater the economic benefit from technological knowledge sharing the more likely a knowledge transaction will (a) occur and (b) be successful.

5 The movement of technological knowledge is generally framed as a concern over transaction costs and benefits. For exceptions, see Grant (1996), Kogut and Zander (1993), and Spender (1996). 


\section{Technological explanations for knowledge exchange}

Technological explanations focus on scientific know-how being shared to advance or improve technology through technological knowledge creation and innovation. In the context of an R\&D task, the emphasis is on problem solving and/or capabilities building. The primary concern is increasing the technological value of the output (product or process as specified by the R\&D task goals). In an effort to achieve an improvement in technological value, scientific know-how is shared to meet current needs or capitalize on opportunities.

Bartlett and Ghoshal (1991), Henderson and Clark (1990), and Henderson and Cockburn (1994) indicate that innovation (technological knowledge creation) can result from the application of new technological knowledge or the reconfiguring of existing technological knowledge. ${ }^{6}$ In R\&D problem solving activities, new kinds of technological knowledge and complementary assets may be needed. Kogut and Zander (1992: 391) suggest that the organizational ability of a firm ("combinative capabilities") can "generate new combinations of existing knowledge." Bartlett and Ghoshal (1991) suggest that innovation in an MNE must include R\&D activities that result in creation as well as adaptation. According to Zander (1998: 19), the MNE "can gain unique advantages from the international exchange of technological knowledge both across and within individual technologies."

The resource-based view and the literature that focuses on dynamic capabilities (Teece, Pisano, \& Shuen, 1997) emphasize that the firm has an ongoing need for continuous development of knowledge and capabilities. As Iansiti and Clark (1994) suggest, problem solving activities in the context of $\mathrm{R} \& \mathrm{D}$ tasks are the basis of technological knowledge creation. They are also the basis for building technological capabilities. In the case of $\mathrm{R} \& \mathrm{D}$, where the major focus is on innovation, the need to share scientific knowhow takes on even greater significance. Technological knowledge building activities develop the "stocks" (accumulation of resources) described by Dierickx and Cool (1989). From an evolutionary perspective, these stocks (technological knowledge and capabilities) can be understood to be the direct result of past experiences (history) with different technologies. As Iansiti and Clark (1994) suggest, accumulation of experience in an activity provides both a current output (in terms of product or process) and new capabilities (that can be used in future R\&D tasks). Accumulation of experience also contributes to success in technological knowledge sharing. The ability to communicate (send) and the ability to understand (receive) relevant technological knowledge may depend on prior experiences. Taking Cohen and Levinthal's (1990: 128) treatise on absorptive capacity and applying it to a within-firm context, "the ability to evaluate and utilize [internal] knowledge is largely a function of the level of prior related knowledge."

Firm size is related to base of technological knowledge (Patel \& Pavitt, 1999). All things equal, a multinational, multidivisional firm will be more technologically diversified than a firm in a more limited geographic and product market. Such "multitechnology" reflects the need to combine and apply an array/assortment of many advances in specialized fields of knowledge (Patel \& Pavitt, 1999: 193). Large firms have greater internal competencies than small firms (Baldwin, Hanel, \& Sabourin, 1999). "Large firms are not only more likely to adopt advanced technology but they also combine greater numbers of advanced technologies" (Baldwin et al., 1999: 8).

"Criticality" (Gupta \& Govindarajan, 1991) or importance of the technology being shared also suggests that a group or projectspecific need exists. A primary motivation for technology sharing is to access specific technological knowledge that can assist in R\&D problem solving. Sharing may take place because the technological knowledge is not available within the R\&D group but can be accessed from another R\&D group (source) within the MNE. Based on the technological rationale presented in this section, the following proposition is offered.

Proposition 2. The greater the technological benefit from technological knowledge sharing the more likely a knowledge transaction will (a) occur and (b) be successful.

\section{Organizational explanations for knowledge exchange}

Organizational (strategy, structure, and systems) explanations focus on technological knowledge being shared to build a coordinated or integrated R\&D network that can effectively utilize or leverage assets/resources dispersed within the MNE. The emphasis is on building an organizational context that encourages or even requires cooperation and collaboration between R\&D groups (Iwata, Kurokawa, \& Fujisue, 2006). Such a context can result in greater intra-firm sharing. In terms of organization structure, some degree of interdependence between R\&D groups is needed. As Grant (1996: 114) states, "A knowledge-based view of the firm encourages us to perceive interdependence as an element of organizational design and the subject of managerial choice." In terms of strategy, coordination and interdependence are precursors to ensure that local (R\&D task) maximization does not overwhelm the need for global (corporate) optimization. In terms of management initiatives, formal systems and mechanisms are needed that support integration and coordination.

In "Managing Technology in the Decentralized Firm," which draws on a 30-year program of research conducted by scholars at M.I.T. and Northwestern University, Rubenstein (1989: xx) forms the "principal conclusion" that there is "no general, definitive 'solution' to the problem of how to organize ... firms are still seeking this elusive solution." Stopford (1995: 34), in Competing Globally for Resources, indicates that "we are currently in a period of great experimentation in both firm strategy and organizational form."

${ }^{6}$ DeBresson and Amesse (1991: 363) cautions that "Inter-disciplinary exchanges can at times perversely result in cross-sterilization" owing to more confusion than clarification. 
Studies of the MNE, however, have described the need to build a transnational entity (Bartlett \& Ghoshal, 1991). The emphasis is on the organization and management of the MNE — and the R\&D function in particular - as an integrated network (Bartlett \& Ghoshal, 1991 ). This "transnational solution" has the organizational systems and processes to support mutual cooperation and learning. One study describes a "metanational" organization that focuses specifically on knowledge integration within the MNE (Doz, Asakawa, Santos, \& Williamson, 1997). Metcalfe and Gibbons (1989: 167) suggest that performance is inseparable from the way the firm structures and articulates its knowledge base; "Some coordination is necessary because specialization and division of labor implies that each individual has command of only a small part of the relevant knowledge base."

As Bartlett and Ghoshal (1991: 128) state, "the most important requirement for facilitating transnational innovations is that the organizational configuration be based on a principle of reciprocal dependence among units." Systems must be set up where it makes sense to share (Almeida, Song, \& Grant, 2002; Liu, Qian, \& Chen, 2006). An organization structure of reciprocal dependence among units is typically described as having interdependence of resources and responsibilities rather than autonomy. Elevated levels of competition and autonomy between R\&D groups can have a negative impact on technological knowledge sharing (O'Sullivan, 2003).

Building a coordinated or integrated R\&D network - one where technological knowledge flow between R\&D groups is important - raises the issue of availability of resources. Sharing scientific know-how requires that specialized technological knowledge available in other R\&D groups can be accessed when needed (Cummings \& Teng, 2006). This requires building sufficient "slack" into the organization to (1) support sharing of technological knowledge and (2) facilitate the activities that contribute to the creation and/or diffusion of technological knowledge. Sufficiency, however, is not the only measure of slack in the organization; quality of the slack resources should also be a consideration (Cummings \& Teng, 2006; O'Sullivan, 2003). Some redundancy between R\&D groups may improve the degree of learning that takes place when technological knowledge sharing occurs. As Cohen and Levinthal (1990) suggest, absorptive capacity can facilitate such learning. Redundancy between R\&D groups can provide the resources needed to increase absorptive capacity.

Reasons for building an organizational context that encourages and rewards cooperation and collaboration among globally dispersed R\&D groups may be to economize on the costs of formal corporate coordination and integration as well as the costs of undertaking technological knowledge transactions. As Rubenstein (1989) suggests, coordination may be more efficient (less expensive) if informal technological knowledge transactions can be undertaken. If a network is in place and some formal ties are established, informal technological knowledge transactions may occur more frequently and this may translate into lower coordination costs (Almeida et al., 2002). In summarizing empirical work, Rubenstein (1989) indicates that informal technological knowledge exchanges can be more effective than formal exchanges. Based on the organizational explanations presented in this section, the following is put forth.

Proposition 3. The greater the organizational benefit from technological knowledge sharing the more likely a knowledge transaction will (a) occur and (b) be successful.

\section{Geographic explanations for knowledge exchange}

"Spatial perspectives on the firm have received far less attention than either technology-oriented or strategy and organization views of the firm" (Hagstrom \& Chandler, 1999: 7-8). Physical proximity plays a role in communication and interaction. DeBresson and Amesse (1991) note that some innovative activity is localized while other such activity is not. The benefits of proximity may diminish as the technology progresses; the very factors contributing to technological advance may be drawn from an increasingly larger space (Freel, 2003; O'Sullivan, 2003). Organizational groups in the same firm located in different areas can overcome topographic distances (DeBresson \& Amesse, 1991: 371). Belonging to the same firm generates many of the advantages of proximity (DeBresson, 1989). An internalized trans-territorial network can overcome limitations imposed by the insulation and compartmentalization of local technological knowledge. Despite physical distance, a scientist in one locale may be willing to contact a fellow scientist within the same firm located many time zones away. If there is no personal relationship (direct or indirect) and there is no face-to-face contact, there is no practical difference between being separated by $20 \mathrm{~m}$ or $2000 \mathrm{~km}$. There may even be some favorable disposition toward the novelty of a request from afar (Ensign, 2009).

Allen $(1970,1977)$ studied communication patterns within a single corporate R\&D laboratory, finding that spatial proximity encouraged collaboration by generating informal communication. Morton (1971) found that the best means of stimulating communication between laboratories separated by physical distances of 10-150 mi was to join them by an organizational bond at the lowest possible level consistent with group size and common technology. Tomlin (1979) studied dialogue between individuals in different R\&D project groups where the R\&D function was broken down by geography, i.e., physically distributed among six primary and ten secondary locations. He reported that communication was unlikely in this situation of geographically dispersed R\&D, but that department commonality increases the likelihood of communication, as does similarity in "technical focus" (work content).

Technological knowledge is neither static nor fixed; Zander (1998) chronicles shifts in the geographical location of technological capabilities in the MNE. His data show that dispersion and duplication of technological knowledge offer flexibility and potential for learning among organizational groups. Zander (1998: 19) points out that MNEs "gain unique advantages from the international exchange of technological knowledge both across and within individual technologies." Corroborating DeBresson and Amesse (1991), Zander (1998: 27) finds that "the age of a technology might influence the pattern of dispersion." His analyses suggest that important technological knowledge tends to be more geographically dispersed than less important technological knowledge. 
Although Cantwell and Janne (2000) point out that the generation, geographical location, and diffusion of technological activity within the MNE is incompletely understood, interdependence between internationally dispersed innovative activities strengthens knowledge flows and linkages across country borders. By consciously shifting to global strategies (geographically dispersed research facilities), the MNE gains access to "complementary paths of technological development" (Cantwell \& Janne, $2000: 245)$. However, Cantwell and Janne (2000: 255) caution that innovative activity will cluster if it is dependent on tacit and complex knowledge; spatial patterns (agglomeration) reflect this, technological networks are more concentrated for knowledge that is difficult to exchange. According to Cantwell and Iammarino (1998: 386) :

... the creation of new networks of transactions is extremely sensitive to geography, the knowledge base matters increasingly at local/regional level, and economic growth requires the creation and improvement of endogenous capabilities, which are highly path-dependent and geographically-specific.

Cardinal and Hatfield (2000: 251) indicate that locating R\&D workers together increases communication among them; this results in skill transfer and knowledge sharing. Technological knowledge is difficult to transfer because it is socially embedded, such friction may be overcome through co-location of $\mathrm{R} \& \mathrm{D}$ workers. The reach for technological knowledge may be quite wide and cover great distance either to search for pockets of knowledge or because of intentional strategies (Ensign, 1999; Freel, 2003). That is, the firm may be drawn to particular localized sources of technological know-how or have an organizational network in place for the purpose of technological learning (Cantwell \& Santangelo, 1999).

While there exists very real gains from search and acquisition of physically distant knowledge, the costs and barriers to be overcome are substantial. There may be an unwillingness to share knowledge for fear of losing control of the resource (losing rents from the resource). In addition to the impediments imposed by the sender, there may be reluctance on the part of the recipient to accept the knowledge - the not-invented-here syndrome. Even within a multinational network, learning may be considered situated in that it involves socialization. Such interaction often requires physical proximity; communication builds relationships and expectations for future behavior. Simply put, "interaction and knowledge exchange benefit from geographical proximity" (Zander \& Solvell, 2000: $58)$.

Proposition 4. The greater the physical proximity of the knowledge sharing participants the more likely a knowledge transaction will (a) occur and (b) be successful.

\section{Sociological explanations for knowledge exchange}

Sociological explanations focus on technological knowledge being shared to improve upon or because of social relationships between individuals and/or groups of individuals dispersed within the R\&D function of the MNE. Technological knowledge transactions may be undertaken to maintain an existing social relationship or cultivate new ones. From this vantage, the emphasis is on: (1) relationships that can result in better communication and an increase in interactions/exchanges or (2) the exchange taking place to take advantage of a social relationship. Thus, relationships may be viewed as an antecedent to or consequence of knowledge exchange (Ensign, 2009).

Exchanges may be direct— A provides B a favor and B returns that favor to A — and temporally, exchanges may be immediate (unlikely for intangible resources such as knowledge) or delayed. It should be pointed out that a connection or tie between A and B may cause $\mathrm{A}$ to share with $\mathrm{B}$, while $\mathrm{B}$ returns favor to $\mathrm{C}$ at some point and $\mathrm{C}$ ultimately returns favor to $\mathrm{A}$. A community or a social network creates the necessary conditions for indirect reciprocity (diffuse exchange). These social relationships are often described in terms of: strength, history, reciprocity, trust, and reliability (Lee, Wong, \& Chong, 2005).

Social networks provide a more suitable means than the faceless market for exchange of intangibles such as technological knowledge. Hagstrom and Chandler (1999: 12) document "the greater emphasis firms seem to be putting on using informal means for managing the organization." Networks allow evaluation while ensuring payment for transactions involving know-how (DeBresson \& Amesse, 1991). Monetary exchange "is impossible because of the embeddedness of technological know-how and the non-exclusive character of its exchange ... durable networks drastically reduce opportunistic behavior" (DeBresson \& Amesse, 1991: 368).

Over the years, scholars have viewed the firm as a social system. As Granovetter (1992: 26) states, "one ... reason why people conduct their economic activity through networks of known personal acquaintances is that sociability, approval, status, and power are central human motives." Schrader (1991) indicates that informal interpersonal trading of technology may be facilitated by the strength of the relationship that exists between a recipient and a source. This relationship is often based on a history of working together. Strength of an interpersonal tie is a "combination of the amount of time, the emotional intensity, the intimacy ..., and the reciprocal services that characterize the tie" (Granovetter, 1973: 1361). Although social relationships may generally not instill sufficient reason for technology trading, reciprocity can be an important motivation in a technological knowledge transaction (Schrader, 1991). Bouty (2000) finds that the social dimension is essential to knowledge exchange among R\&D workers. The notion of an "obligation to reciprocate" (Schrader, 1991: 155) is consistent with concepts in economic exchange (Carter, 1989) as well as social exchange (Emerson, 1976 ).

A body of theoretical and empirical literature supports the concept that social interaction (Nonaka, 1994; Tyre \& von Hippel, 1997; Wu \& Tsai, 2005) and social exchange (Emerson, 1976) are important in a firm. He sums up his position by stating:

"Exchange theory" is not to be taken as a theory. ... it is a frame of reference that takes the movement of valued things (resources) through social process as its focus. ... its scope is defined by an assumption: that a resource will continue to flow only if there is a valued return contingent upon it. Psychologists call this contingent return reinforcement- 
economists call this reciprocally contingent flow exchange.... I like to think of social exchange theory as developing the conceptual tools needed (longitudinal exchange relations and network structures) to deal with exactly those topics that economics theory has trouble with (Emerson, $1976: 359$ ).

In a discussion on exchange networks in reference to "resource distribution within corporate groups," Emerson (1976: 357) also indicates that "the idea of productive exchange readily accommodates large numbers of actors, thereby freeing exchange theory from its dyadic format."

The literature suggests that communication is an important element in social exchange and that face-to-face communication can be effective in building strong social relationships. Williams and Gibson (1990: 13) indicate that "boundary spanning" is an important concept in understanding the communication process of technological knowledge sharing. They state:

The communication involved in the technology transfer process often takes place between individuals using different vocabularies, styles, channels, schedules, and reward systems. Formal and informal communication barriers exist between different cultures, different sciences, and different levels of abstraction in what is being transferred (Williams \& Gibson, 1990 : 13).

Both Saxenian (1991) and Sitkin (1986) find evidence that friendship and trust influence knowledge sharing. In addition to these, knowing the source can provide credibility to the exchange. It can contribute to a feeling that the source is reliable. In effect, knowing the source is equivalent to knowing the reliability of the source's technological knowledge. Based on empirical work, Szulanski (2000) reports that a recipient's perception regarding the reliability of the source's technology does have an impact on the success of the technology transfer. There is an element of "trust" as well as an element of "value" to the technological knowledge.

Looking at the transfer of "best practices" as a problem (stickiness), Szulanski (2000) emphasizes that there can be a negative side to social relationships. In his research, he finds that transfer problems are often related to a barren organizational context, an arduous relationship, and a lack of motivation by source and/or recipient. This supports von Hippel's (1994) findings that there are problems (stickiness) associated with the outright transfer of knowledge. In the case of globally dispersed R\&D groups in an MNE, cultural distance may also have a negative effect on success in social relationships. The result may be diminished magnitude or effectiveness of technological knowledge transactions. Based on the sociological motives presented in this section, the following proposition is suggested.

Proposition 5. The greater the sociological benefit from technological knowledge sharing the more likely a knowledge transaction will (a) occur and (b) be successful.

\section{Complementarity and conflict among the explanations}

All five explanations for knowledge sharing must be considered in assessing the cost/benefit trade-offs that are involved in decisions related to undertaking a knowledge transaction. It may be the case that certain factors are primary and others supporting, and this may be conditional - that is, contingency theory is applicable. The firm administrator can take strategic decisions designed to integrate globally dispersed knowledge found in R\&D groups within the MNE. Future research must assess formal and informal mechanisms for knowledge sharing and knowledge building. Measurement of success depends on the perspective taken. From an economic point of view, did the knowledge exchange translate into a profit? From the technological vantage, was technology advanced? A very useful knowledge transaction may result in the valid understanding that an avenue should not be pursued; does this represent progress (Williams \& Gibson, 1990: 12)?

According to Patel and Pavitt (1999: 192), firms are embedded in complex technological, organizational, and economic worlds with "so many variables and interactions that it is impossible fully to model, predict and control their behavior through explicit and codified theories and guidelines." Patel and Pavitt (1999) indicate that the administrator makes progress through step-by-step experimentation. Experimentation leads to improvement in knowledge and knowledge leads to improvement in experimentation.

In terms of the various processes available for combining knowledge among distributed R\&D groups, it is important to be explicit about the ways in which these add value for the firm (Buckley \& Carter, 1999). There are clearly a multitude of actors involved and a wide range of means for sharing knowledge. Its occurrence and success are very much dependent on the mechanisms and individuals. The effectiveness, speed, and costliness of alternative approaches is influenced by the location of the R\&D workers within the firm, whether this is geographically or organizationally by product or function (Buckley \& Carter, 1999: 90-91). Buckley and Carter (1999: 93) point out that for successful sharing of knowledge the source (i.e., the provider of knowledge) must "recognize the knowledge requirements of the recipient in order to provide what is appropriate, in a form that is appropriate, and with appropriate timing." To these words of wisdom, it should be added that the recipient (i.e., the receiver of knowledge) holds a portion of this burden and in cases when the technological knowledge was requested or initiated by them they may hold greater responsibility still (Ensign, 2009). Also to be included is consideration of search and scanning costs.

Zander and Solvell (2000: 45-46) find social and geographic explanations are conjoined, indicating "higher probability of chance encounters [through the] inertia of social links" and that "Amount of knowledge exchange tends to be sensitive to increasing geographic distances." Advising against relentless pursuit of technology sharing among R\&D workers, Zander and Solvell (2000: 56) suggest that "some parts of the innovation process are more suited for cross-border exchange" and this calls for a 
"more fine-tuned approach to knowledge exchange and innovation management in a networked multinational." Iwata et al. (2006: 361) find independence may be a suitable means for acquiring knowledge; "autonomous R\&D subsidiaries promoted knowledge flows from local environments to the subsidiary."

Co-location is a confluence of social, organizational, and geographic variables. There is a need for work that "illuminates critical relationships between the geographical dimension, phases of the innovation process, and the typical content or form of knowledge exchange" (Zander \& Solvell, 2000: 56). Future empirical work needs to be able to measure such variables. Recording social factors would necessitate examining individuals and the groups to which they belong. Sociological data might examine past behavior and expected action. Organizational observations would include an array of strategy, structure, and systems that have bearing on the decision to share or not share technological knowledge. Geographic explanations might require looking at physical separation, cultural distance, or other considerations (e.g., time zones, political divide, or language). In fact, many theories of exchange may be characterized as matters of distance. Technological distance: commonalities and differences in scientific know-how among actors. Sociological distance: strength, number, and pattern of direct and indirect ties. Organizational distance: overlap or separation among groups or units.

Economic considerations arise at a variety of levels - from individual interaction to industry competition. Determination of interpersonal knowledge sharing within the firm may take into account what can and cannot occur within the firm (as well as from a strategic vantage - what should and should not occur within the confines of the firm). Examining knowledge exchange with a strategic lens reveals not only what transactions take place inside the firm but where. The strategic perspective provides a look into the present and future. Forcing attention to multi-period, multi-party issues draws in economic and organizational concerns.

Different types of R\&D groups undertake different types of sharing for different reasons (Nobel \& Birkinshaw, 1998). Organizational structure (integration, dependence) and socialization provide the means to govern knowledge exchange (Nobel \& Birkinshaw, 1998). Though theory might suggest that these two modes of control are substitutes for governing knowledge exchange, Nobel and Birkinshaw (1998) find that they are used in conjunction - they may be complements. "Socialization is necessary to build the linkages between units, but at the same time there have to be clearly defined standards to ensure compatibility" (Nobel \& Birkinshaw, 1998: 491).

\section{Conclusion}

This paper has considered various factors that may influence the sharing of knowledge among R\&D workers. Stobaugh and Wells (1984) note that variables affecting the transfer of technological knowledge can be manipulated by the administrator. To that end, it is conceivable that the goals or intent of knowledge sharing may cause the manager to influence those parameters that can be dictated - organization systems, structure, etc. While cultural and physical distance may be unalterable, such factors can be taken into account in the design of channels for technological knowledge sharing. Cantwell and Santangelo (1999: 119) find that firms are purposefully "dispersing their R\&D facilities over greater geographical distances." Hagstrom and Chandler (1999: 1) draw attention to the presence of "overlaps (and also some conflicting arguments)" in the various theoretical lenses applied in the study of the multidivisional, multinational firm. Such commonalities and differences in theory are to be "welcomed as they indicate both inquisitiveness and vitality" (Hagstrom \& Chandler, 1999: 1). It is hoped that this paper will serve to foster examination leading to reconciliation of the various perspectives. Consideration of one explanation without controlling for the others runs the risk of hardearned empirical conclusions being discounted.

Adams, J. D. (1999). Endogenous R\&D spillovers and industrial research productivity. Paper presented at American Economic Association Annual Meeting. New York, NY.

Allen, T. J. (1970). Communication networks: $R \&$ D laboratories. Cambridge, MA: MIT Working paper.

Allen, T. J. (1977). Managing the flow of technology: Technology transfer and the dissemination of technological information within the $R \& D$ organization. Cambridge, MA: MIT Press.

Almeida, P., Song, J., \& Grant, R. M. (2002). Are firms superior to alliances and markets? An empirical test of cross-border knowledge building. Organization Science, 13(2), 147-161.

Arrow, K. J. (1971). Essays on the theory of risk bearing. Chicago, IL: Markham.

Baldwin, J., Hanel, P., \& Sabourin, D. (1999). Determinants of innovative activity in Canadian manufacturing firms: The role of intellectual property rights. Ottawa, Ontario: Micro-Economics Analysis Division, Statistics Canada.

Bartlett, C. A. (1984). Organization and control of global enterprise: Influences, characteristics and guidelines. Paper presented at Harvard Business School $75^{\text {th }}$ Anniversary Colloquium on Competition in Global Industries.

Bartlett, C. A., \& Ghoshal, S. (1991). Managing across borders: The transnational solution. Boston, MA: Harvard Business School Press.

Bouty, I. (2000). Interpersonal and interaction influences on informal resource exchanges between R\&D researchers across organizational boundaries. Academy of Management Journal, 43(1), 50-65.

Buckley, P. J., \& Carter, M. J. (1999). Managing cross-border complementary knowledge: Conceptual approach to knowledge management in multinational firms. International Studies of Management \& Organization, 29(1), 80-104.

Cantwell, J., \& Iammarino, S. (1998). MNCs, technological innovation and regional systems in the EU: Some evidence in the Italian case. International Journal of the Economics of Business, 5(3), 383-408.

Cantwell, J., \& Janne, O. (2000). The role of multinational corporations and national states in the globalization of innovatory capacity: The European perspective. Technology Analysis \& Strategic Management, 12(2), 243-262. 
Cantwell, J., \& Santangelo, G. D. (1999). The frontier of international technology networks: Sourcing abroad the most highly tacit capabilities. Information Economics and Policy, 11(1), 101-123.

Cardinal, L. B., \& Hatfield, D. E. (2000). Internal knowledge generation: The research laboratory and innovative productivity in the pharmaceutical industry. Journal of Engineering and Technology Management, 17(3), 247-271.

Carter, A. P. (1989). Knowhow trading as economic exchange. Research Policy, 18(3), 155-163.

Chandler, A. (1962). Strategy and structure: Chapters in the history of the American industrial enterprise. Cambridge, MA: MIT Press.

Cohen, W. M., \& Levinthal, D. A. (1990). Absorptive capacity: A new perspective on learning and innovation. Administrative Science Quarterly, 35(1), 128-152.

Collins, J. D., \& Hitt, M. A. (2006). Leveraging tacit knowledge in alliances: The importance of using relational capabilities to build and leverage relational capital. Journal of Engineering and Technology Management, 23(2), 147-167.

Commons, J. R. (1934). Institutional economics. Madison, WI: University of Wisconsin Press.

Cummings, J. L., \& Teng, B. -S. (2006). The keys to successful knowledge-sharing. Journal of General Management, 31(4), 1-18.

DeBresson, C. (1989). Innovation clusters and location: Some skeptical notes about Canada. Baltimore, MD: Association of American Geographers.

DeBresson, C., \& Amesse, F. (1991). Networks of innovators: A review and introduction to the issue. Research Policy, 20(5), 363-379.

De Meyer, A. (1991). Tech talk: How managers are stimulating global R\&D communication. Sloan Management Review, 32(3), 49-58.

Dierickx, I., \& Cool, K. (1989). Asset stock accumulation and sustainability of competitive advantage. Management Science, 35(12), $1504-1511$.

Dodgson, M. (1993). Learning, trust, and technological collaboration. Human Relations, 46(1), 77-95.

Doz, Y. L., Asakawa, K., Santos, J. F. P., \& Williamson, P. J. (1997). The metanational corporation. Fontainebleau, France: INSEAD Working paper.

Dunning, J. H. (1958). American investment in British manufacturing industry. London, UK: Allen Unwin. Emerson, R. M. (1976). Social exchange theory. Annual Review of Sociology, 2, 335-362.

Ensign, P. C. (1999). Innovation in the multinational firm with globally dispersed R\&D: Technological knowledge utilization and accumulation. Journal of High Technology Management Research, 10(2), 203-221.

Ensign, P. C. (2009). Knowledge sharing among scientists: Why reputation matters for R\&D in multinational firms. London, UK: Palgrave Macmillan.

Ensign, P. C., Birkinshaw, J. M., \& Frost, T. S. (2000). R\&D centres of excellence in Canada. In U. Holm, \& T. Pedersen (Eds.), The emergence and impact of MNC centres of excellence: A subsidiary perspective. London, UK: Palgrave Macmillan.

Freel, M. S. (2003). Sectoral patterns of small firm innovation, networking and proximity. Research Policy, 32(5), 751-770.

Gopalakrishnan, S., \& Santoro, M. D. (2004). Distinguishing between knowledge transfer and technology transfer activities: The role of key organizational factors. IEEE Transactions on Engineering Management, 51(1), 57-69.

Granovetter, M. S. (1973). The strength of weak ties. American Journal of Sociology, 78(6), 1360-1380.

Granovetter, M. (1992). Problems of explanation in economic sociology. In N. Nohria \& R.G. Eccles (Eds.), Networks and organizations: Structure, form, and action. Boston, MA: Harvard Business School.

Grant, R. M. (1996, Winter). Toward a knowledge-based theory of the firm. Strategic Management Journal, 17, $109-122$.

Gupta, A., \& Govindarajan, V. (1993). Coalignment between knowledge flow patterns and strategic systems and processes within MNCs. In P. Lorange, B. Chakravarthy, J. Roos, \& A. Van de Ven (Eds.), Implementing strategic processes: Change, learning and co-operation. London, UK: Blackwell.

Gupta, A. K., \& Govindarajan, V. (1991). Knowledge flows and the structure of control within multinational corporations. Academy of Management Review, 16(4), 768-792.

Hagstrom, P., \& Chandler, A. D., Jr. (1999). Perspectives on firm dynamics. In A. D. Chandler Jr., P. Hagstrom, \& O. Solvell (Eds.), The dynamic firm: The role of technology, strategy, organization, and regions. Oxford, UK: Oxford University Press.

Håkanson, L., Nobel, R. (1998). Technology characteristics and reverse technology transfer. Paper presented at Academy of International Business Annual Meeting. Vienna, Austria.

Håkanson, L., \& Zander, U. (1986). Managing international research \& development. Stockholm, Sweden: En Mekanpublikation.

Hansen, Morten Timme. (1996). Knowledge integration in organizations. Ph.D. dissertation. Stanford University.

Hayton, James C., \& Zahra, Shaker A. (2005). Venture team human capital and absorptive capacity in high technology new ventures. International Journal of Technology Management, 31(3/4), 256-274.

Henderson, R. M., \& Clark, K. B. (1990). Architectural innovation: The reconfiguration of existing product technologies and the failure of established firms. Administrative Science Quarterly, 35(1), 9-30.

Henderson, R., \& Cockburn, I. (1994, Winter). Measuring competence? Exploring firm effects in pharmaceutical research. Strategic Management Journal, 15, 63-84.

Iansiti, M. (1998). Technology integration: Making critical choices in a dynamic world. Boston, MA: Harvard Business School Press.

Iansiti, M., \& Clark, K. B. (1994). Integration and dynamic capability: Evidence from product development in automobiles and mainframe computers. Industrial and Corporate Change, 3(3), 557-605.

Iwata, S., Kurokawa, S., \& Fujisue, K. (2006). An analysis of global R\&D activities of Japanese MNCs in the US from the knowledge-based view. IEEE Transactions on Engineering Management, 53(3), 361-379.

Katz, J. S., \& Martin, B. R. (1997). What is research collaboration? Research Policy, 26(1), 1-18.

Kuemmerle, W. (1997). Building effective R\&D capabilities abroad. Harvard Business Review, 75(2), 61-70. 
Katz, R., \& Tushman, M. (1979). Communication patterns, project performance, and task characteristics: An empirical evaluation and integration in an R\&D setting. Organizational Behavior and Human Performance, 23(2), 139-162.

Kogut, B. (1983). Foreign direct investment as a sequential process. In C. P. Kindleberger, \& D. Audretsch (Eds.), The multinational corporation in the 1980s. Cambridge, MA: MIT Press.

Kogut, B. (1990). International sequential advantages and network flexibility. In C. A. Bartlett, Y. Doz, \& G. Hedlund (Eds.), Managing the global firm. London, UK: Routledge.

Kogut, B., \& Zander, U. (1992). Knowledge of the firm, combinative capabilities, and the replication of technology. Organization Science, 3(2), 383-397.

Kogut, B., \& Zander, U. (1993). Knowledge of the firm and evolutionary theory of the multinational corporation. Journal of International Business Studies, 24(4), 625-645.

Lane, P. J., \& Lubatkin, M. (1998). Relative absorptive capacity and interorganizational learning. Strategic Management Journal, $19(5), 461-477$.

Lee, S. -H., Wong, P. -K., \& Chong, C. -L. (2005). Human and social capital explanations for R\&D outcomes. IEEE Transactions on Engineering Management, 52(1), 59-68.

Leonard-Barton, D. (1990). The intraorganizational environment: Point-to-point versus diffusion. In F. Williams \& D.V. Gibson (Eds.), Technology transfer: A communication perspective. Sage: Newbury Park, CA.

Liu, J. -J., Qian, J. -Y., \& Chen, J. (2006). Technological learning and firm-level technological capability building: Analytical framework and evidence from Chinese manufacturing firms. International Journal of Technology Management, 36(1/2), 190-208.

Lorsch, J.W. (1964). Organizational structure and scientific transfer: A study of differentiation and integration in complex organizational systems. DBA dissertation. Harvard University.

Mansfield, E. (1968). Industrial research and technological innovation: An econometric analysis. New York, NY: W.W. Norton \& Company.

Mansfield, E. (1968). The economics of technological change. New York, NY: W.W. Norton \& Company.

Metcalfe, J. S., \& Gibbons, M. (1989). Technology, variety and organization: A systematic perspective on the competitive process. In R. S. Rosenbloom \& R.A. Burgelman (Eds.), Research on technological innovation, management and policy. Greenwich, CT: JAI Press.

Morton, J. A. (1971). Organizing for innovation: A systems approach to technical management. New York, NY: McGraw Hill.

Nobel, R., \& Birkinshaw, J. (1998). Innovation in multinational corporations: Control and communication patterns in international R\&D operations. Strategic Management Journal, 19(5), 479-496.

Nonaka, I. (1994). A dynamic theory of organizational knowledge creation. Organization Science, 1(5), 14-37.

O'Sullivan, A. (2003). Dispersed collaboration in a multi-firm, multi-team product development project. Journal of Engineering and Technology Management, 20(1), 93-116.

Patel, P., \& Pavitt, Keith (1999). The wide (and increasing) spread of technological competencies in the world's largest firms: A challenge to conventional wisdom. In A. D. Chandler Jr., P. Hagstrom, \& O. Solvell (Eds.), The dynamic firm: The role of technology, strategy, organization, and regions. Oxford, UK: Oxford University Press.

Powell, W. W., Koput, K. W., \& Smith-Doerr, L. (1996). Interorganizational collaboration and the locus of innovation: Networks of learning in biotechnology. Administrative Science Quarterly, 41(1), 116-145.

Rubenstein, A. H. (1989). Managing technology in the decentralized firm. New York, NY: John Wiley \& Sons.

Sakakibara, M. (1999). Knowledge sharing in cooperative research and development. Paper presented at American Economic Association Annual Meeting. New York, NY.

Santoro, M. D., \& Saparito, P. A. (2006). Self-interest assumption and relational trust in university-industry knowledge transfers. IEEE Transactions on Engineering Management, 53(3), 335-347.

Saxenian, A. (1991). The origin and dynamics of production networks in Silicon Valley. Research Policy, 20(5), $423-437$.

Schrader, S. (1991). Informal technology transfer between firms: Cooperation through information trading. Research Policy, 20(2), 153-170.

Sitkin, S. (1986). Secrecy in organizations: Determinants of secrecy behavior among engineers in three Silicon Valley semiconductor firms. Ph.D. dissertation. Stanford University.

Soh, P. H., \& Roberts, Edward B. (1998). Learning by knowing through social capital: A missing link to research capability. Cambridge, MA: International Center for the Research on the Management of Technology, MIT Working paper.

Spender, J. -C. (1996, Winter). Making knowledge the basis of a dynamic theory of the firm. Strategic Management Journal, 17, 45-62.

Stobaugh, R., \& Wells, L. T. (Eds.). (1984). Technology crossing borders: The choice, transfer, and management of international technology flows. Boston, MA: Harvard Business School Press.

Stock, G. N., Greis, N. P., \& Dibner, M. D. (1996). Parent-subsidiary communication in international biotechnology R\&D. IEEE Transactions on Engineering Management, 43(1), 56-68.

Stopford, J. M. (1995). Competing globally for resources. Transnational Corporations, 4(2), 34-57.

Szulanski, G. (2000). The process of knowledge transfer: A diachronic analysis of stickiness. Organizational Behavior and Human Decision Processes, 82(1), 9-27.

Tarn, D. D. C. (2006). Industry as the knowledge base: The way Asians integrate knowledge from academic, industrial, and public sectors. International Journal of Technology Management, 34(3/4), 360-378.

Teece, D. J., Pisano, G., \& Shuen, A. (1997). Dynamic capabilities and strategic management. Strategic Management Journal, 18(7), 509-533. 
Thrift, N. (1985). Flies and germs: A geography of knowledge. In D. Gregory \& J. Urry (Eds.), Social relations and spatial structures. London, UK: Palgrave Macmillan.

Tomlin, B. (1979). Dyadic technical communication in a geographically-dispersed research organization. Ph.D. dissertation. M.I.T. Cambridge, MA.

Tsai, W. (2001). Knowledge transfer in intra-organizational networks: Effects of network position and absorbtive capacity on business unit innovation and performance. Academy of Management Journal, 44(5), 996-1004.

Tushman, M. L., \& Katz, R. (1980). External communication and project performance: An investigation into the role of gatekeepers. Management Science, 26(11), 1071-1085.

Tyre, M. J., \& von Hippel, E. (1997). The situated nature of adaptive learning in organizations. Organization Science, 8(1), 71-81.

von Hippel, E. (1994). "Sticky information" and the locus of problem solving: Implications for innovation. Management Science, 40(4), 429-439.

Williams, F., \& Gibson, D. V. (Eds.). (1990). Technology transfer: A communication perspective. Newbury Park, CA: Sage.

Williamson, O. E. (1970). Corporate control and business behavior. Englewood Cliffs, NJ: Prentice-Hall.

Williamson, O. E. (1975). Markets and hierarchies: Analysis and antitrust implications. New York, NY: Free Press.

Wu, W. -Y., \& Tsai, H. -J. (2005). Impact of social capital and business operation mode on intellectual capital and knowledge management. International Journal of Technology Management, 30(1/2), 147-171.

Yang, J. (2008). Unravelling the link between knowledge integration and new product timeliness. Technology Analysis \& Strategic Management, 20(2), 231-243.

Zander, I. (1998). The evolution of technological capabilities in the multinational corporation-Dispersion, duplication and potential advantages from multinationality. Research Policy, 27(1), 17-35.

Zander, U., \& Solvell, O. (2000). Cross-border innovation in the multinational corporation: A research agenda. International Studies of Management \& Organization, 30(2), 44-67. 